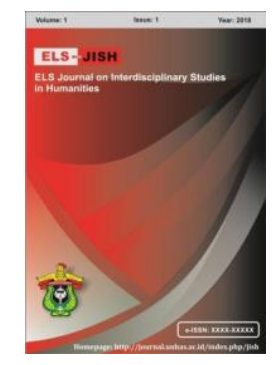

ELS-JISH

ELS Journal on Interdisciplinary Studies on Humanities

Volume 3 Issue 2, 2020

ISSN (print) : 2621-0843

ISSN (online) : 2621-0835

Homepage : http://journal.unhas.ac.id/index.php/jish

\title{
Teacher's Feedback in Intensive Speaking Program
}

\author{
Madani ${ }^{1}$, Ahmad Munir ${ }^{2}$, Tengsoe Tjahjono ${ }^{3}$ \\ ${ }^{1}$ madanilabugi.mlb@gmail.com
}

\begin{abstract}
Interaction plays a very important role in the classroom between students and teachers. This research was conducted to study the ways teachers initiate the interaction and give feedback to the students' responses and was also meant to find out the students' and teachers' views towards their interaction in the classroom. Case study was conducted in an English institution mediating the teachers and students with different goals in the context of one student and one teacher in a class. This study employed observation to see the ways teachers initiate the interaction and give feedback to the students' responses. Interview was undertaken to know students' and teachers' views towards their interaction in the classroom. There were 5 cases observed. This research was conducted following the series of data collection, data reduction, and data display. Interview was conducted to help gain the views from students and teachers. The result shows that the teachers initiated the interaction and gave feedback by employing all strategies with different frequency. However, student was also found to give initiation which gave much contribution to the continuation of the interaction during the teaching and learning process. It is really recommended for the next researchers to study on the non-linguistic strategies employed by teachers to initiate and give feedback since they were also found during the observation of this study.
\end{abstract}

Keywords: Interaction, Feedback.

How to cite: Madani., Munir, A., \& Tjahjono, T. (2020). Teacher's Feedback in Intensive Speaking Program. ELS Journal on Interdisciplinary Studies in Humanities, 3(2), 187-197. DOI: 10.34050/els-jish.v3i2.10370

\section{Introduction}

Interaction plays an essential role in any kind of language classes including English. To keep interaction going well in the classroom, it is really helpful for both teachers and students to understand each other since it provides learning opportunities for the students and possibilities of idea development for the teachers to keep the classroom situation going. Furthermore, in teaching and learning process, teachers should incorporate different strategy, method, or learning style in order to create successful learning with the students and lead them to be more enjoyable and comfortable strategy (Riski, H., Rahman, F., Sadik, A. (2018)). Walsh (2011: 2) emphasizes that if teachers try to improve their teaching and learning processes, they should pay much attention to their interaction in the classroom. He really

1,2,3 Universitas Negeri Surabaya, Indonesia. 
addresses the importance of interaction between teachers and students during their teaching and learning processes. As important, Liu and Le (2012: 9) suggest teachers to improve their language use in order to have a satisfying result of what they have done in the classroom.

Going deeper to the importance of interaction, Yousefi and Koosha (2013: 3320) argued that only interaction is not enough. The students and teachers should have the opportunity to exchange ideas and to express their idea so it will increase the way they use English to improve their ability even though not all classroom interactions really give a positive contribution to the students. Even giving students most part to do the interaction is not really useful. However, Choudhury (2005: 81) concludes that what the learners actually do need is an environment which has an access for them to their productive selves in smooth way. Therefore, it is obvious that the teacher plays a significant part to bridge the students to the helpful and supportive interaction during their teaching and learning processes time in the classroom in order to achieve the better learning outcome.

The reality that teachers have difficulty in keeping the interaction going in the classroom is everywhere, as in TAF English. TAF English is an English course which helps everyone, from kids to adult, who wants to learn English by providing the private English program in a classroom. Private maintenance program means the teaching and learning processes runs with only one student and one teacher in a classroom. In the setting of private maintenance program, the problem exists when the student does not want to response the initiation from the teachers longer or when the teachers run out of idea of what to talk about. Besides, the way teacher gives feedback to the students will affect the continuation of the students' speech. Keeping the interaction in such private situation is difficult since if there is no interaction between student and teacher, then the situation will be awkward. It gradually leads to the fact that observing the ways of how teacher gives feedback to keep the interaction running in such context is important. The feedback strategies follow Sinclair \& Coulthard (1975: 36) and Fawbush (2010: 19) which are evaluation, comment, sustaining strategy, explicit correction, recast, clarification request, metalinguistic feedback, elicitation, and repetition.

Some previous researches about interaction (Kasim (2004); Aldabbus (2008); Nugent (2009); Rashidi and Rafieerad (2010); Ibrahim (2012); Suryati (2015)) emphasize the importance of meaningful interaction between students and teachers in the classroom. It makes it clearer that analyzing their interaction patterns and strategies is very fundamental to be explored. Since teacher is the one who mostly controls the classroom interaction, a research is needed to see specifically how teacher's give feedback to the student's responses in order to see the interaction keep going in the classroom, more specifically in the context of one teacher, one student in a class.

Additionally, most of the previous researches, instead of saying all, are in the context of formal class of government and private schools where the numbers of students are a lot while in fact, interaction in relatively small or even private class is also found in the teaching and learning of English. This research then tries to elaborate the topic in the context of private teaching and learning 
between student and teacher, instead of a whole-class interaction. In the private context, the interaction between teacher and student happens more intensive and focused so both teachers and students may have barriers to keep their interaction running since they are just two independent roles to run the interaction. In that way, the way to keep the interaction going will easily be analyzed and the interaction between student and teacher will easily be captured.

It is really expected that this kind of research benefits the performance of the English teachers in the classroom to keep the meaningful interaction going on in order to arrive at the objectives set at the beginning of the lesson and moreover to the students to do best in their English classes.

\section{Method}

This study was a qualitative research. It was a case study in an English institution which helped each individual English learner as a student, with the setting of one coach and one student in a class. It followed what Ary, Jacobs, and Sorensen (2006: 29) stated that a case study focuses on a single unit and is to arrive at a detailed description and understanding of entity. Besides, Bhattacherjee (2012: 95) stated that case study is focusing on the phenomenon in its natural setting intensively. This study then focused on the phenomena that happened in the classroom, especially the feedback done by teachers within his/her interaction with student. After observing, interview was conducted to get the views from students and teachers.

\subsection{Respondents}

The subjects of this study were the teachers and the students of an English institution named TAF English where the teachers were usually referred to as coach (es) so the term coach and teacher may be used interchangeably but they refer to the same object. During the study, there were five cases observed meaning that there were five observed classes with one coach and one student for each class. The choosing of the subjects concerned to any learning schedules of Intensive Speaking Program that were available to be observed in the institution meaning that the students confirmed to come and to have the class. Besides, the private setting of the program was also one of the considerations. Private setting referred to the condition of one-on-one teaching and learning class where each individual student was given lesson by a coach so there were only two of them in the classroom.

\subsection{Procedure}

The methodology of this research followed the steps suggested by Miles, Huberman, and Saldana (2014: p 31-33) which are data collection, data display, and conclusion drawing with some adaption. Non-participant observation was done to collect the data by video recording the whole class from the beginning until the last. All recorded data were manually transcribed. After that, the obtained data were shown following the classifications of how teachers gave feedback. Coding was applied to present the data. Letter code T represented teacher(s) and letter code $S$ represented student(s) while number following them represented the setting where they were in when the observation was 
done. All teachers are females. S1 and S2 are females and S3, S4, and S5 are males. After those two steps, conclusion was finally drawn by explaining how teachers gave feedback.

\section{Findings}

\subsection{How Teachers Give Feedback}

This study finally comes to findings of how teachers gave feedback to the student's response during their session. Teachers gave feedback by giving evaluation, comment, sustaining strategy, explicit correction, recast, clarification request, metalinguistic feedback, and elicitation.

\section{a. Evaluation}

Teacher does this by evaluating the student's response. Evaluating in this case means that the teacher gives comments on the quality of the students' responses. The followings are the examples of teachers doing it.

T1: That's right. And the subject?

S1: They.

T1: Yes, Good!. Ok, the next one. "There are good adults and bad adults, but it is the young heroes that stop the bad ones". Which one is the subject and which one is the verb?

In the example, the teacher evaluates the student's response by saying "That's right...." and "Yes, Good!..." in order to appreciate her effort to respond to the teacher's initiation. Another example of doing evaluation was when the teacher said "Yes, good." and "good, upset." when the student answers the question correctly as featured in the following dialogue.

S2: A to G, Ok. No. 1, when a person thanks someone for something, Grateful.

T2: Yes, good. It is grateful

S2: When a person is angry about something is upset.

T2: good, upset..

\section{b. Comment}

In giving feedback, coach sometimes comments on the response given by the students. The comment may vary depending on responses from student as shown below.

S2: Actually her husband is a ..... he has many knowledge and experience so that her being a everything, being a pilot, being a business woman.

T2: Ok, then. So I think heroes in Indonesia is not like heroes in the past. Like they... heroes in the past they give a concrete result. But I think now, they are more like uummm... give big contribution.

In the example, the teacher gives feedback by giving her opinion about what she thinks of the term hero which was done by the student first and they 
are exchanging the ideas of the term hero. For that moment, the teacher takes her time to tell about her opinion on the word hero.

\section{c. Sustaining Strategy}

Sometimes coach just wants the students to continue speaking and focuses listening to them as provided on the dialogue below.

T3: Hmm it's okay. So you are going to talk about your parents, right?

S3: Yes.

\section{T3: Hehem}

S3: I had parents.

In the example, the coach gives the sign for the student to continue his explanation about his parents by saying "Hehem". It gives the student sign that it is okay to continue his explanation about his parents and so he does.

\section{d. Explicit Correction}

Another way for the teacher to give feedback is by doing explicit correction. Coach sometimes gives correction explicitly addressing the mistake done by students during the class as can be seen below.

S1: are children.

T1: are, are-nya saja. Only "are". Ok, that'll be the verb. Nice! After that, "There are adults but they are not the stars". Which one is the subject?

S1: uuuummmmm......

In the dialogue, the teacher actually gives a correction explicitly by telling the students what is the correct answer. It is when the teacher asks the student to find out the verb of a sentence and the student says, "are children." So the teacher directly tells that it is only the word are not the word children. The other example is as given below.

\section{S1: Muscle itu apa miss?}

T1: Muscle, bacanya bukan [muskel] dear, tapi [musel]. Muscle itu otot, tapi kalau muscly itu berotot.

From the example, the student asks the meaning of the word muscle to the coach. Then, the coach firstly explicitly corrects the pronunciation of the student to say the word muscle before telling her the meaning of the word muscle

\section{e. Recast}

The other way for teacher to give feedback on the response of the students is recast. This way is when the teacher reformulates the whole sentence of the student except the incorrect one because the teacher corrects it without telling the students they are making mistakes on their sentence. In this case, however, teacher is actually meaning to show the student the correct one. This condition also happens during the class as shown below.

S3:The trees falling down. 
T3: The trees fell.

In the dialogue, the student actually makes mistake on the point of grammar. The teacher then repeats the sentence by saying the correct one without telling the student the mistake but just shows the correct one. The teacher also uses the intonation of not blaming or correcting the student. Another example of teacher recasting is when the student says, "one in month". The teacher models the correct way to express what the student is actually willing to say by saying "Oh, once in one month". It is then followed by the student saying the correct one, "Once in one month. In Jemur.".

S5: My father in law's house, one in month.

T5: Oh, once in one month.

S5: Once in one month. In Jemur.

\section{f. Clarification Request}

Sometimes teacher does not get the point of what the student is saying. In order to let the interaction go on, the teacher is doing clarification to the student to ensure the message trying to be delivered by the student. The example of teacher doing clarification request is provided below.

S1: On 28th .

T1: 28th of July you mean? Ok. Alright then. It's still a week more. OK, no problem. Good luck with that. But how did you feel? Was it difficult? Or was it something like, yaah, just so-so.

\section{S1: Difficult}

In the dialogue, the teacher is asking the student for clarification about the date she mention, "28th of July you mean?" which is the date of the result announcement of her registration to a university. She then answers it and the dialogue continues on. The other example of clarifying is provided below.

T2: You first said that she didn't attend university?

S2: Yes, but now she can give lesson to the university, many university and lecturer.

In the example, the teacher confirms what the student said before, "You first said that she didn't attend university?" when they talked about a female minister of Indonesia. The student then answers, "Yes, but now she can give lesson to the university, many university and lecturer.", and continues on explaining the case which makes the interaction possible to happen.

\section{g. Metalinguistic feedback}

Metalinguistic feedback is the way teacher gives feedback by commenting on the metalinguistic mistakes as grammar and pronunciation done by the students. In this strategy, the teacher is explaining the way and to show how to get it right. The followings are the example dialogues of a teachers giving metalinguistic feedback to the student's response.

S1: Yah. Berarti seharusnya gimana miss? 
T1: "can"-nya yang bisa diubah jadi verb 2. Dan verb 2-nya adalah "could".

S1: Berarti I couldn't ........

T1: He'em. Jadi kalo ada could disitu diikuti verb 1. I could wear, I could read. Kalau tidak ada cooknya baru verb 1-nya bisa dijadikan verb 2.

S1: Jadi "could" itu verb 2 miss?

T1: Yah verb 2-nya harusnya di "could"-nya bukan setelahnya.

S1: Berarti I cannot wore, salah.

T1: Yah, I cannot wear, right? Bukan I cannot wore. Kalau I cannot wore tidak bisa. "Could wear" harusnya.

In the example, teacher is giving an explanation about getting the grammar correct. At the beginning, the teacher and the student talk about the use of verb 2 in the sentence. They then continue discussing the use of cannot and they end up discussing couldn't + verb 1 . It is obvious that the students finally get the point of her teacher.

\section{h. Elicitation}

The next strategy for the teacher to keep the interaction going is by doing the elicitation. The elicitation can be performed by simply pausing so that the student can continue and finish what the teacher is about to say. The second, the teacher can ask questions to the students in order to elicit from them. And the last one is asking the students to reformulate their answers. The following dialogues show the example of teacher applying elicitation in their own respective classes.

T1: Yes, Good!. Ok, the next one. "There are good adults and bad adults, but it is the young heroes that stop the bad ones". Which one is the subject and which one is the verb?

S1: This is verb miss. (pointing the book)

T1: Which one?

S1: are.

T1: Ok. And the subject?

S1: Subject.

T1: Uhumb. Which one is the subject?

S1: There

T1: Yes. It is the young heroes that stop the bad ones. Which one is the subject?

S1: The young heroes.

In the example, the teacher is doing elicitation to the student related to the sentence parts in one part of their class. The teacher addresses one by one the part of sentence so she can see the comprehension of her student. Even though the student answer unsurely, her answer is actually correct. The other example of teacher doing elicitation is given below. 
T2: So, overall what can you do in Rio De Janeiro?

S2: What can we do? We can do everything. We can enjoy the life of the people in many activities in the beach, and we can see soccer, we can surfing, and many famous buildings like Christ The Redeemer statue, and also we can see the barrier between the slum people with the rich people.

This is a discussion between student and teacher after watching a short video about Rio De Janeiro, Brazil. The teacher elicits the information from the student by asking her about things she can do in Rio De Janeiro, Brazil. She then answers the questions by telling the teacher what she just watched in the video because she has never been to Rio De Janeiro, Brazil before. By that, the student has the chance to speak and elaborate more about the topic they are discussing.

Table 1. Table of Appearance Frequency

\begin{tabular}{lccccc}
\hline \multicolumn{1}{c}{ Feedback Strategy } & $\mathbf{1}^{\text {st }}$ & $\mathbf{2}^{\text {nd }}$ & $\mathbf{3}^{\text {rd }}$ & $\mathbf{4}^{\text {th }}$ & $\mathbf{5}^{\text {th }}$ \\
\hline Evaluation & 5 & 7 & 4 & 0 & 5 \\
\hline Comment & 0 & 1 & 2 & 1 & 0 \\
\hline Sustaining strategy & 0 & 0 & 2 & 8 & 1 \\
\hline Explicit correction & 6 & 0 & 8 & 1 & 9 \\
\hline Recast & 0 & 0 & 3 & 1 & 5 \\
\hline Clarification request & 1 & 4 & 7 & 5 & 5 \\
\hline Metalinguistic feedback & 3 & 0 & 6 & 3 & 5 \\
\hline Elicitation & 12 & 14 & 7 & 7 & 3 \\
\hline
\end{tabular}

\section{Discussion}

Generally, most of the strategies of giving feedback are done by the coaches (teachers). The teachers try their best to make sure that there is an interaction between them and the students during the session. There are many strategies employed by the teachers to give feedback to the students' response like giving evaluation, comment, sustaining strategy, explicit correction, recast, clarification request, metalinguistic feedback, and elicitation. Elicitation becomes the most frequently employed strategy by the teachers to give feedback to the students' responses. Elicitation is done by some ways such as pausing to allow students to continue, questioning the students to elicit the forms, or asking the students to reformulate their sentences which make the interaction run longer.

The other strategy which is employed by teacher is explicit correction. It is employed by the teacher because of some reasons. It may be because the time is limited to just elicit from the students which takes time, or the teachers have specific time at the end part of the lesson to really correct the error which teacher notes during the class, or simply because the student and teacher agree to do the correction right after the students make the mistake. That links to the fact that teachers do not do recast often since they want to be clear 
straight to the point of what they want to address so it does not take time. As found, recast was only done by teachers who have cognitively high level students and teacher who has cognitively low level student states that it is better for her to do the explicit correction so the student knows what is being address by the teacher to her instead of being confused what the teacher actually means to teach her. It goes with Veliz (2008) who discovered that recast is only effective for the cognitively advanced students. However, the researcher suggested teachers to not only solely accept all utterances by the students but also to correct them. For the researcher, recast seems to be just effective for special students but what is important to note is that teachers should pay attention to all students' utterances in order to avoid the errors maximally. This also agrees with Gitsaki and Althobaiti (2010) who researched on the same topic examining seven types of corrective feedback employed by teachers in their classroom toward beginner and intermediate learners. Their result shows that high quality students are easier in understanding the implicit corrective feedback than the low quality students. Strategies as explicit correction, metalinguistic clues, clarification request, and recast were employed to intermediate students while the most frequently used feedback type to beginner students was explicit correction, clarification request, and recast. So basically all students benefit from the use of corrective feedback. The problem is only on the time they need in order to understand the feedback which means that teacher should be very careful in delivering their corrective feedback to the students because, if not, it may lead to fossilization. It is crucial to avoid the fossilization off ill-formed structures by the students (Rezaei, 2011).

The next strategy in giving feedback employed by the teachers is sustaining strategy which allows the students to continue because they want to listen to longer speech from the students. However, one coach thinks that this strategy leads to the fact that students do not continue speaking because they are even confused what the teacher wants them to do. The interesting fact is that the students are mostly honest and opened to the teachers about their condition either they understand the lesson or not so it makes the teacher easier to elaborate more on what the students do not really understand about. As Allwright comments that classroom interaction should be managed by everyone taking part, not just by teacher, because interaction is not something the teacher does to students, but something that teachers and students do together. During the observation, it is clearly seen that they both have the mutual work to make the class interaction successful. That goes with Kasim (2004) who studied classroom interaction in English Department Class involving the teacher and students who were taking Speaking II class at the English Department that revealed the fact that nine interactional strategies were used by the teacher and ten by the students which shows the mutual work between students and teachers in running the class and making the interaction meaningful.

In short, both teachers and students contribute to the flow of the class interaction and teachers' feedbacks determine how the interaction is expected to continue on. Teachers employ many kinds of giving feedback which are good to really reach the study objectives with students of different background and needs. 


\section{Conclusion}

To sum up, teachers employ 8 (eight) kinds of feedback strategy with elicitation as the most frequently employed strategy. It is really recommended to all teachers to study the various strategies of giving feedback as they are important in helping reach the study objectives and make students feel good and not blamed with teacher's ways of giving correction which will hopefully lead to them enjoying the class.

\section{References}

Aldabbus, Shaban. (2008). An Investigation into the Impact of Language Games on Classroom Interaction and Pupil Learning in Libyan EFL Primary Classrooms. (Unpublished Thesis submitted for the degree of Doctor of Philosophy Integrated PhD in Education). Newcastle University School of Education, Communication, and Language Sciences. Newcastle.

Ary, Donald, Lucy Cheser Jacobs, and Chris Sorensen. (2010). Introduction to Research in Education. Wadsworth: Cengage Learning.

Bhattacherjee, Anol. (2012). Social Science Research: Principles, Methods, and Practices, 2nd Ed. Zurich: Creative Commons Attribution 3.0 License, Jacobs Foundation.

Bogdan, Robert C. and Sari Knopp Biklen. (2007). Qualitative Research for Education An Introduction to Theory and Methods, 5th Ed. Boston: Pearson Education Inc.

Choudhury, Shaheena. (2005). Interaction in Second Language Classrooms. BRAC University Journal, 2 (1), pp. 77-82.

Fawbush, Ben. (2010). Implicit and Explicit Corrective Feedback for Middle School ESL Learners. Minnesota: Retrieved from https://www.lappublishing.com

Ibrahim, Mahmoud Elsayed Hamed. (2012). Classroom Interaction in Second Language Teaching and Learning in the Vocational Education Development Centre (VEDC). (Unpublished Dissertation submitted in partial fulfillment of Master of Education). TESOL Faculty of Education.

Jones, Sarah. (2009). Application of the Sinclair and Coulthard Discourse Model to a Korean University English Conversation Course. Retrieved from www.birmingham.ac.uk/Documents/college.../JonesSD .pdf .

Kasim, Usman. (2004). Classroom Interaction in the English Department Speaking Class at State University of Malang. Jurnal IImu Pendidikan, Oktober 2004, 11 (3).

Liu, Jingxia and Le Thao. (2012). A Case Study on College English Classroom Discourse. International Journal of Innovative Interdisciplinary Research Issue 2 ISSN 1839-9053.

Love, Robert. (2012). Using IRF Pattern to Analyze Classroom Interaction. Retrieved from 
www.academia.edu/5145333/Using_the_IRF_pattern_to_analyse_classro om_interaction_undergraduate_assignment_2012_robert love irf

Miles, Matthew B., A. Michael Huberman, and Johnny Saldana. (2014). Qualitative Data Analysis: A Methods Sourcebook. California: SAGE Publications, Inc.

Nassaji, H. and Wells, G. (2000). What's the Use of "Triadic Dialogue"?: An Investigation of Teacher-Student Interaction. Applied Linguistics, 21 (3). Pp. 376-406.

Nugent, Tisome T. (2009). The Impact of Teacher-Student Interaction on Student Motivation and Achievement. A dissertation submitted in partial fulfillment of the requirements for the degree of Doctor of Education in the Department of Educational Research, Technology and Leadership in the College of Education at the University of Central Florida Orlando, Florida.

Rashidi, Nasser and Rafieerad, Mahshid. (2010). Analyzing Patterns of Classroom Interaction in EFL Classrooms in Iran. The Journal of Asia TEFL, 7 (3), pp. 93-120, Autumn 2010.

Riski, H., Rahman F., \& Sadik, A. (2018). Improving the Students' Speaking Ability through Silent Way Method at SMU Negeri 12 Makassar. Jurnal IImu Budaya, 6(2), pp. $303-312$.

Sinclair, John McHardy \& Coulthard, Malcolm. 1975. Towards an Analysis of Discourse. London: Oxford University Press.

Stojkovic, Marija. (2012). Using the Sinclair and Coulthard Model of Discourse Analysis for Examining Classroom Communication in University Level ELT. Univerzitet u Nišu Filozofski Fakultet.

Suryati, Nunung. (2015). Classroom Interaction Strategies Employed by English Teachers at Lower Secondary Schools. TEFLIN Journal, 26 (2), July 2015 http://dx.doi.org/10.15639/teflinjournal.v26i2/247-264.

Walsh, Steve. (2011). Exploring Classroom Discourse: Language in Use. New York: Routledge.

Yousefi, Azam and Koosha, Mansour. (2013). A Descriptive Study of Teacher/Learner Interactions at the MA Level of the Fields of Teaching English as a Foreign Language, General Linguistics, and Translation Studies. International Research Journal of Applied and Basic Sciences (IRJABS), 4 (11), 3312-3323. 